\title{
RELATIONSHIP BETWEEN CLIMATE CHANGE AND FOOD SECURITY: A CASE STUDY ON THE NORTHERN REGION OF MALAYSIA
}

\author{
Rabiul Islam, Ahmad Bashawir Abdul Ghani \\ School of International Studies, University Utara Malaysia, Sintok, Kedah, Malaysia. \\ rabiul@uum.edu.my, bashawir@uum.edu.my
}

Article History: Received on $25^{\text {th }}$ February 2019, Revised on $30^{\text {th }}$ April 2019, Published on $30^{\text {th }}$ May 2019

\begin{abstract}
Purpose of the Study: Climate change is an international agenda and entails a worldwide clarification. It is trendy now in Southeast Asia and the nastiest is yet to originate. In recent years, addressing climate change has been high on the global strategic program. There is now consent to avert worldwide heating and attainment of hazardous stages, which can be accomplished through mechanisms of alleviating conservatory gas releases. The target of this paper is to decide the linkages of the aspects of climatic variations and domestic resiliencies through the level of domestic food security among the deprived and squat revenue households in the Northern Region of Malaysia.
\end{abstract}

Methodology: In this study, the Northern Region of Malaysia covers four states, namely, Perlis, Kedah, Penang, and Perak. The current learning is founded on the primary data that were composed from March to June, 2018 over a questionnaire review of 400 deprived and less revenue families from the Malaysian states of Perlis, Kedah, Penang, and Perak. The sample was designated from E-Kasih poor domestic database founded on a cluster random sampling system.

Educational Implications: Primarily, the study is about the events of family nourishment safety according to the United States Agency for International Development - Household Food Insecurity Access (USAIDHFIA) model, and takes track of ordinal regressions under the Logit and Probit models.

Results: This study discovered that nourishment uncertainty is related to community and financial issues, and is also expressively related to climatic issues. Therefore, nutrition safety programs must be assimilated with the programs for climatic change variation.

Novelty: The innovation of this paper is the indicator of environmental sustainability in the Northern Region of Malaysia

Keywords: Climate Change, Food Security, Poverty, Resilience, Northern Region of Malaysia.

\section{INTRODUCTION}

The 2008 international food crisis provides as an overture to an extra sensitive nutrition catastrophe in the upcoming. Consequently, nutrition safety is a state matter for numerous states. The most important food security distress is about the manufacturing process being adequate for household utilization and having the capacity and right to use food in international arcades. Sustainable nutrition safety at the domestic level is similarly significant as nationalized nutrition safety is not adequate to make certain justifiable nutrition safety measures at the domestic echelon. The drivers of domestic food safety are in fact more decisive at the general stage as nutrition safety is demarcated in its maximum essential system as access to nutrition by all persons at all periods is required for the well-being (FAO, 2003). As such, the hub of nutrition safety would be the essential component in humanity at the domestic level. This division is essential as actions intended for humanizing domestic nutrition safety could be reasonably diverse from persons expected at humanizing nutrition safety universally.

Climate change consumes an inordinate influence on numerous segments. Food safety is one of them. Climate variation is upsetting farming, with possessions erratically dispersed diagonally across the sphere. The association between environmental variation and farming is a vibrant concern for food safety. Influences of environmental variation can be clarified in both encouraging and adverse practices. In most of the investigations in food safety surroundings in emerging nations, manifold gauges are recycled to reproduce the numerous extents of hitches. Some of the most frequently used types of gauges in the valuation of food safety situations are food invention, income, total disbursement, food expenditure, share of food spending, calorie ingestion, nutritional eminence, etc. (Riely et al., 1999). International sustenance safety is a severe contest to manhood and has occurred more extremely since the instability of food value in 2007-2008. Food safety is catching the focus of international dissertation and has become an issue of national policy and public apprehension (Bala et al., 2014; Riely et al., 1999; Giraldo et al., 2008). 
Climate change (CC) is projected to have significant influences on the quality, obtainability, and possession of staple food. Nutriment safety is resulted by three key mechanisms: (a) adequate accessibility to nutriments, (b) access to nutriments, and (c) superiority and consumption of nutriments in terms of both nutritious and ethnic viewpoints (FAO, 1996). With the prophesied growth in populace on a worldwide foundation, the current exhaustive contributions into main cornflakes and rice will only provide marginal increases in yields. In the context of CC influences, the variations in worldwide climate outlines could have a deep impact on the creation and distribution of adequate primary diets (Paterson and Lima, 2010, 2011).

Malaysia is a fast emerging nation with an impartially varied and reduced Carbon dioxide (CO2) releases in Malaysia need improved by $221 \%$ through the 1990-2004 periods (EIA, 2005). The state is currently single of the 30 biggest conservatory vapor emitters. Universal heating is predictable to lift the temperature by $0.3-4.5^{\circ} \mathrm{C}$. Radiator disease determination aim marine equal to upsurge by around $95 \mathrm{~cm}$ ended a hundred-year epoch and variations in precipitation between $-30 \%$ to $+30 \%$. It wills main to a decrease in harvest produce and reason dearth in numerous parts, creation it durable to promote certain harvests (MOSTE, 2001). Furthermore, predictions designate which concentrated regular rain determination progress by $51 \%$ in East Coast Economic Region, though lowest rainfall determination decline between $32 \%$ and $61 \%$ for the entire Peninsular Malaysia. Therefore, the yearly rainwater might increase by up to $10 \%$ in the East Coast economic region and in the North-West Coast, and reduce by up to 5\% in the Central and Southern regions of Malaysia (NAHRIM, 2006). Tisdell (1996) treasured the precipitation erraticism that surged the flat of ecological pressure, which touched the competence of the structure to preserve the output.

As environmental variation is unique of the main possible pressures to the countrywide nutrition safety in Malaysia, it has a durable option which weather variation is related to the domestic nutrition safety of the nation. In order to certify nutrition sanctuary and appropriate strategy preferences in Malaysia, it is very significant to learn the present state of family nutrition safety and the relation among the changes in variables of climate, supportable nutrition safety, and so on, at the domestic front. Some of the lessons showed the influences of variables of climate and the results on the domestic nutrition safety in Malaysia. The current study is a demeanor of a painstaking learning on this subject. The outcomes of this learning might be supportive for representatives in their suggestions to set marks in state growth tactics on nutrition safety, socioeconomic improvement, scarcity assuagement, and achievement of Dream 2020, in order to develop a completely industrialized nation by 2020 .

\section{LITERATURE REVIEW}

Food security can be examined in a number of ways at the household, community, national, and individual levels. At the community level, various local organizations and NGOs in Europe, Canada, and the United States have now begun to focus on building food security within their own communities. Community food security has been defined as "a condition in which all community residents obtain a safe, culturally acceptable, and nutritionally adequate diet through a sustainable food system that maximizes the community's self-reliance and social justice. It has also been argued that an approach to increase community food security requires an understanding of how communities interact with resources in their social and physical environments over extended periods of time. Specific attention to food security at the community level focuses on strategies that address broad systemic issues that can affect the availability, accessibility, affordability, and quality of food present in markets (Campell, 1991).

The FAO (2010) describes household food security as the application of the concept at the family level, with individuals being the focus of concern within households. Household preferences may not prioritize the acquisition of food over other goods and services, such as school fees and housing. Furthermore, key characteristics in the definitions of household food security include food access, sufficiency, security, time, and perceptions (Maxwell and Smith, 1992).

Many variables can affect food security at the household and individual levels. Factors affecting food insecurity can include demographic variables, such as household size/composition, migration, ethnicity, region, and/or age and gender of individuals (Haddad et al., 1994). As well, fluctuations in crop production, food supply and food prices, on- and offfarm employment, and patterns in morbidity are all examples of variables that have been used as proxy measures for food security (Balatibat, 2004). Haddad et al. (1994) note a variety of indirect variables that can be used to predict food insecurity at the household level, including land ownership, access to credit, and sale of assets including livestock.

Food security is the most commonly used social sustainability indicator in the assessment of food security conditions, such as food production, food self-sufficiency level, income, total expenditure, food expenditure, share of food expenditure, calorie consumption, nutritional status, etc. (Riely et al., 1999). Food security is a worldwide problem that 
has caught the attention of governments and the scientific community. It particularly affects developing countries. The scientific community has increasing concerns for strategic understanding and implementation of food security policies in developing countries, especially since the food crisis in the 1970s. The process of decision-making is becoming increasingly complex due to the interaction of multiple dimensions related to food security (Giraldo et al., 2008).

Marine fisheries make vital contributions to food security - both as a direct source of protein, essential fatty acids, and micronutrients, and indirectly via employment and income for food purchases. Global marine fisheries supply the world with approximately 80 million tons of protein- and micronutrient-rich food for human consumption per year. There is compelling evidence that climate change caused significant changes in global oceans, such as increase in ocean temperature, ocean acidification, and sea level rise during the twentieth century. These trends are expected to continue into the next century under the climate change scenarios considered by the Intergovernmental Panel on Climate Change. Climate change is expected to affect the target species through a range of direct and indirect mechanisms (IPCC, 2007). Direct effects include changes in reproduction, distribution, and population dynamics of fish stocks. Indirect effects include changes in productivity and composition of ecosystems on which fish depend for their food and shelter. Assessing fisheries' vulnerability to climate change can identify countries that are highly exposed to hazards related to climate change, countries that are highly dependent on fisheries for food security, employment, and economic value, and countries that limited resources and societal capacity constrain adaptation, thus enhancing the need for decision-making to reduce such vulnerabilities and secure the future sustainability of marine fisheries (FAO, 2016). Vulnerability assessments are at the heart of efforts to prioritize and execute adaptation investments from scarce global funding in ways that address those who most need them the most, and have been receiving increasing attention from policy-makers and academics (Ding et al., 2017).

The concern over food security has been evident for centuries. Thomas Malthus predicted that an increase of population is limited by the means of subsistence and the population growth would eventually supersede global food production (Winch, 1987). Similarly, the Club of Rome's report examined variables, such as world population, industrialization, food production, and resource depletion, and predicted economic and societal collapse by the end of the 20th century (Turner, 2008). Still, agricultural production worldwide has grown more rapidly than global population growth, and there is presently more than enough food, at least in terms of macronutrients, available to feed the world population (Simon, 2012). However, it is important to note that the number of people suffering from food insecurity is reportedly increasing, as is the proportion of the overall population suffering from insufficient food (Simon, 2012).

One of the central focuses in the assessment of food security has been to eliminate hunger and reduce the risks of future hunger. At the world food summit held in Rome in 1996, the Food and Agricultural Organization (FAO) of the United Nations reported that more than 800 million people, predominantly in developing countries, did not have enough food to meet their basic nutritional needs (Blakeney, 2009). The Rome Declaration, issued by the 1996 summit, pledged to cut the number of hungry people in half by 2015. This goal was also included in the Millennium Declaration of the United Nations in 2000 (Blakeney, 2009). Yet in countries, such as India, chronic hunger and malnutrition remain a major concern. Recent evidence reveals that India continues to struggle to reduce nutritional inadequacy despite rapid economic growth, and more than 230 million people continue to go to bed hungry every night (Banik, 2011). Amartya Sen (1999) has stated that hunger relates not only to food production and agricultural expansion, but also to the functioning of the entire economy, including the operation of social arrangements that can influence people's ability to acquire food. Chronic hunger is a consequence of diets persistently inadequate in terms of quantity and/or quality (Sen, 1999). For example, some individuals have chronic hunger due to their very low income, which leads to an inability to buy food for survival (Sen, 1999). Seasonal hunger, on the other hand, is related to cycles of food growing and harvesting. Annual "hunger seasons" can occur when the previous year's harvest stocks dwindle, food prices are high, or jobs in the region are scarce (Vaitla et al., 2009). It is important to note the distinction between having enough food and having enough access to food. Seasonal hunger, for instance, can occur as a result of inadequate food from previous harvests. It can also be a result of the inability to buy food from the market.

\section{METHODOLOGY}

\section{Selection of the Sample Area}

In this study, four states of the Northern Region of Malaysia, namely, Perlis, Kedah, Penang, and Perak, are covered. It is projected that the environment variation in the Northern Region of Malaysia is affected. Eight rural and urban areas were randomly selected from each state of the Northern Region of Malaysia. Thus, the influences of environment variation are 
gravely experienced here. As most of the people living in the Northern Region of Malaysia are engaged in agronomic sector, the influence of weather transformation on the affected agricultural sector creates extra pressure on food security.

\section{Sample Size and Data Collection}

Yamane (1967) provided a basic method to estimate sample sizes. This method was used to analyze the sample sizes for this study. A 95\% confidence level and $\mathrm{P}=.5$ are assumed for Equation 1.

$$
n=\frac{N}{1+N\left(e^{2}\right)}
$$

where $\mathrm{n}$ is the sample size, $\mathrm{N}$ is the population size, and e is the level of precision. When this formula is applied to the above sample, we get Equation 2.

$$
=\frac{5895694}{1+5895694(0.05)^{2}}=399.97 \approx 400
$$

For the experimental calculation, the study relies on main statistics of a review of a household level questionnaire. The Northern Region of Malaysia was selected as the learning area because most of the production covers more than half of the Peninsular Malaysia, especially rice production, which contains a zone of around 32404 square kilometers spread across the states of Perlis, Kedah, Penang, and Perak (Figure 1).

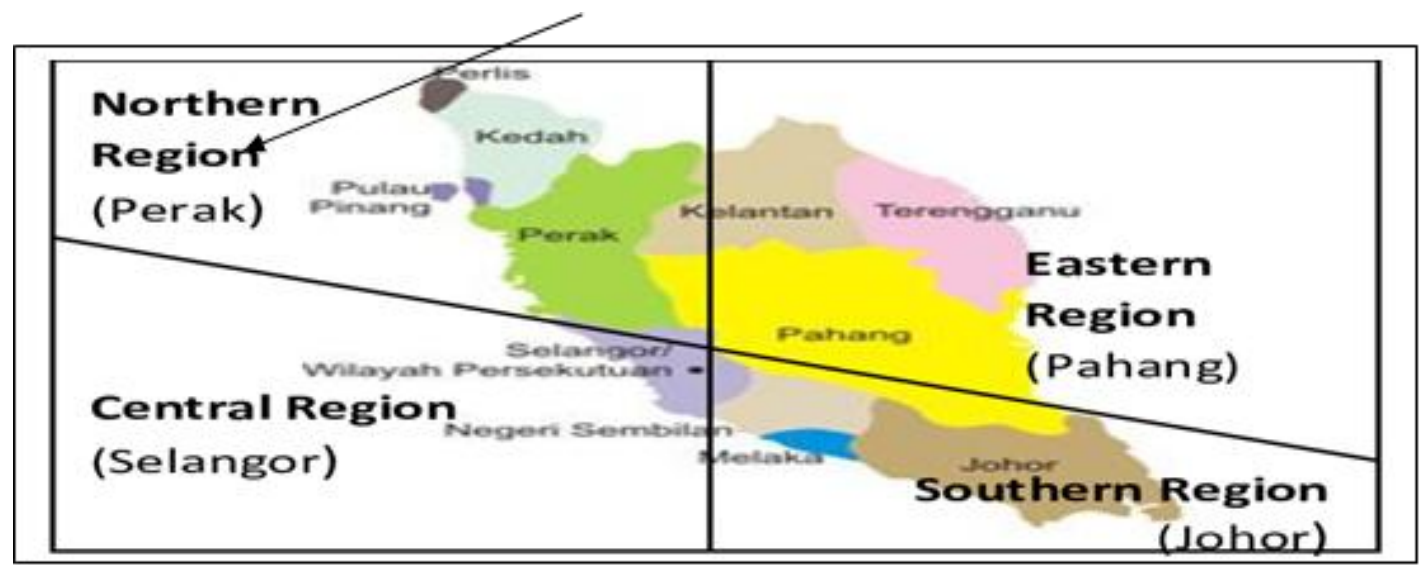

Figure 1. Position of the learning zone (Northern Region of Malaysia)

Source: $\underline{\text { Yuhanz et al. (2016) }}$

The northern area is critical for two maximum motives: (a) The region is the maximum susceptible zone in Malaysia to variations of climate; and (b) the revenue of this region is low-slung and the frequency of scarcity is extraordinary. According to the census (2010), the total population of Malaysia is about 28,334,000; however, according to world population review, it is 32.04 million. The total population of the Northern Region of Malaysia is about 5.9 million (National Census, 2010).

The learning tracks a two-stage cluster random sampling method. Primarily, the models remain gathered by place and then by deficiency group. Lastly, after every group, models are chosen arbitrarily from the E-Kasih database, that is a combined list structure which conscripts pitiable families at the state equal to idea, instrument and display scarcity programs. Firstly, the town zone of Kanger and countryside zone of Arau were designated in a perilous state. Secondly, the town zone of Alor Setar and countryside zone of Changlun were selected from Kedah state. Thirdly, the town zone of Pulau Penang and countryside zone of Gelugor were encompassed from Penang state. Finally, the town zone of Ipoh and countryside zone of Kampar were preferred from Perak state. Established on the method of essential scope of models (Yamane, 1967), a 400-model scope was first designated which conferred to the quantity of inhabitants. In order to confirm a decent amount of explanations for every cluster that is desired to comport a sound numerical scrutiny for any precise assemblage, 50 families were additionally included to the model. However, although the model initially comprised of 450 families, it came down to 400 families after the facts were gathered and authenticated. The last circulation of the composed model is assumed in Table 1. 
Table 1: Dissemination of the model

\begin{tabular}{|c|c|c|c|c|c|c|c|c|c|c|c|}
\hline & Perlis & & Kedah & & Penang & & Perak & & Whole & & Total \\
\hline & Town & $\begin{array}{l}\text { Country } \\
\text { Side }\end{array}$ & Town & $\begin{array}{l}\text { Country } \\
\text { Side }\end{array}$ & Town & $\begin{array}{l}\text { Country } \\
\text { Side }\end{array}$ & Town & $\begin{array}{l}\text { Country } \\
\text { Side }\end{array}$ & Town & $\begin{array}{l}\text { Country } \\
\text { Side }\end{array}$ & \\
\hline $\begin{array}{l}\text { Hard-core } \\
\text { poor }\end{array}$ & 2 & 2 & 3 & 13 & 4 & 9 & 6 & 15 & 15 & 39 & \\
\hline $\begin{array}{l}\text { Poor } \\
\text { Recently } \\
\text { marginally }\end{array}$ & 4 & 3 & 15 & 36 & 9 & 29 & 21 & 40 & 49 & 109 & 54 \\
\hline $\begin{array}{l}\text { non-poor } \\
\text { Marginally }\end{array}$ & 2 & 1 & 10 & 18 & 13 & 9 & 15 & 25 & 40 & & 157 \\
\hline $\begin{array}{l}\text { non-poor } \\
\text { Total target }\end{array}$ & 1 & 1 & 20 & 12 & 12 & 12 & 23 & 15 & 56 & 40 & 93 \\
\hline $\begin{array}{l}\text { group } \\
\text { State total }\end{array}$ & $\begin{array}{l}9 \\
16\end{array}$ & 7 & $\begin{array}{l}48 \\
127\end{array}$ & 79 & $\begin{array}{l}38 \\
97\end{array}$ & 59 & $\begin{array}{l}65 \\
159\end{array}$ & 94 & $\begin{array}{l}160 \\
400\end{array}$ & 240 & $\begin{array}{l}96 \\
400\end{array}$ \\
\hline
\end{tabular}

\section{Model Description}

In order to estimate the association among the domestic position of nutrition safety and the climate variables touching on nutrition safety, the subsequent methodical reliant on deterioration or ordinal regression is showed and founded on logit and probit methods:

$\mathrm{Mi}=(\mathrm{I} 1, \mathrm{I} 2)$

$\mathrm{Zi}=(\mathrm{Z} 1, \mathrm{Z} 2, \mathrm{Z} 3$,

$\mathrm{Mi}=\mathrm{f}(\mathrm{Zi})$

where

I1 = Household food availability in the last one month,

I2 = Household status of food accessibility,

$\mathrm{Z} 1, \mathrm{Z2}, \ldots \ldots \ldots . \mathrm{Z} 36=$ Household and climatic issues related variables

In this paper, the two needy variables, position of nutrition convenience and nutrition obtainability, are recycled as the dimensions of domestic nutrition safety. Domestic nutrition obtainability is founded on the dimension of straight awareness of the domestic, though domestic position of nutrition convenience dimension is founded on the occurrence of scheming. In order to ration the position of nutrition obtainability, families are requested around their nutrition position in the earlier month (see Table 1). In order to quantity the position of nutrition convenience, this learning smears straight calculating questionnaire-based methods established by Coates, Swindale and Bilinsky (2007) for the United States Agency for International Development (USAID), which is recognized as Household Food Insecurity Access (HFIA).

The incline of the sovereign variables of the paper involves diverse flexibility influences of domestic (Z1-Z17) and climate variable influences (Z18-Z36). These variables are measured from four scopes of nutrition safety - obtainability of nutrition, permanence of stock, convenience to nutrition, and operation of nutrition (FAO, 2005; 2008). The obtainability of nutrition earns an adequate amount of superiority nutrition accessible at the domestic flat. The convenience of nutrition means family's admittance to adequate possessions, counting a set of the product packages that a separate can entrée founded on the permissible, monetary, radical, and community preparation of a communal in which they animate for receiving superiority nutriments for a nourishing dinnertime. Nutrition operation displays the implication of non-nutriment contributions in nutrition safety, such as appropriate régime, unsoiled liquid, fitness maintenance and cleanliness, to improvement in nutritious happiness in which all bodily necessities are met. Nutrition scheme constancy denotes to families having entrée to adequate nutrition at all periods even to the opinion that they would have admission to nutrition throughout an abrupt disaster, such as one that is financial or climate-related, or a returning incidence, such as periodic nutrition uncertainties. Here, the pliability rises to the families' size or assets to manage with pressure and adversity in situation of real or predictable nutrition uncertainty that is considered as socioeconomic, corporal properties, and maintenance policy and performance.

In order to check the finest appropriate method and toughness, the learning rumored both the probit and logit models; however for examination, it typically emphases on the logit model. Logit and probit models that appear similar with a sigmoid purpose and an area between 0 and 1, which types both quantile meanings founded on the supposition that the logit model shadows logistic spreading and the probit model shadows a standard dissemination. Normally, the logit model is recycled when every remark has an identical likelihood. Moreover, an association examination is commenced to 
regulate the connection between the pertinent variables and to square the tricky multi-collinearity. Lastly, this learning also validates the way in which the endogeny and connection difficulties are measured.

\section{FINDINGS AND DISCUSSION}

\section{Dimension of Domestic Nutrition Safety}

In rapports of domestic nutrition obtainability, $14.50 \%$ specified which they had sufficient nutrition which they enjoyed, but a great amount of the families $(35.00 \%)$ designated which they did not continuously have sufficient nutrition which they enjoyed, although $10.00 \%$ of the families specified that they often continued starving (Table 2).

Table 2: Domestic nutrition position in the earlier month

\begin{tabular}{lll}
\hline Nutrition position in the household & No. of households & $\%$ of total \\
\hline Adequate of the types of nutrition you need to eat & 58 & 14.50 \\
Adequate but not continuously the types of nutrition you need to eat & 140 & 35.00 \\
Occasionally not adequate to eat & 97 & 24.25 \\
Frequently not adequate to eat & 65 & 16.25 \\
Normally famished & 40 & 10.00 \\
Overall & 400 & 100.00 \\
\hline
\end{tabular}

Domestic nutrition uncertainty contact (designed for every family by transmission a cypher 1-4, where $1=$ nutrition safe admission, 2 = slightly nutrition uncertain admission, $3=$ abstemiously nourishment unconfident admission, $4=$ sternly nutrition unconfident admission.

Table 3: Dissemination of Family Nutrition Uncertainty Admission

\begin{tabular}{lll}
\hline HFIA category & HFIA prevalence & $\%$ of HFIA prevalence \\
\hline 1 = Nutrition safe admission & 196 & 49.00 \\
2 = Slightly nutrition uncertain admission & 95 & 23.75 \\
3 = Abstemiously nourishment unconfident admission & 64 & 16.00 \\
4 = Sternly nutrition unconfident admission & 45 & 11.25 \\
Overall & 400 & 100.00 \\
\hline
\end{tabular}

Constructed on Table 3, this learning discovered that $49 \%$ of the families are underneath the group of "nutrition safe admission". Among the measured families, $23.75 \%$ are opposite slightly nutrition uncertainty (access), who are concerned about not taking sufficient nutrition occasionally or frequently, and/or are incapable to eat favored nutriments, and/or infrequently eat a more droning food than anticipated and/or also infrequently eat some unwanted nutriments. Among the families, $16 \%$ are abstemiously nutrition unconfident. These families frequently sacrifice the quality of food by eating a monotonous diet or undesirable foods and/or decrease the consumption of nutrition infrequently or occasionally. A certain $11.25 \%$ of the families are harshly nutrition unconfident and thus, the necessity to expurgate spinal on mealtime scope or the amount of mealtimes, and/or involvement any of the three most Spartan circumstances consecutively out of nutrition, profitable to divan famished or profitable a entire day and night without consumption.

\section{Family Position of Nutrition Safety and Pertinent Issues}

The regression representations constructed on Equation 3 demonstrated that some of the flexibility issues have a statistically momentous association with family nutrition obtainability and nutrition convenience (Table 4).

Table 4: Relationship between household status of food security and relevant climatic factors

\begin{tabular}{|c|c|c|c|c|c|c|c|c|}
\hline \multirow[t]{3}{*}{ Variable } & \multicolumn{4}{|c|}{ Dependent variable I1 } & \multicolumn{4}{|c|}{ Dependent variable I2 } \\
\hline & \multicolumn{2}{|c|}{ Ordered probit } & \multicolumn{2}{|c|}{ Ordered logit } & \multicolumn{2}{|c|}{ Ordered probit } & \multicolumn{2}{|c|}{ Ordered logit } \\
\hline & $\begin{array}{l}\text { Odds } \\
\text { ratio }\end{array}$ & Prob. & $\begin{array}{l}\text { Odds } \\
\text { ratio }\end{array}$ & Prob. & $\begin{array}{l}\text { Odds } \\
\text { ratio }\end{array}$ & Prob. & $\begin{array}{l}\text { Odds } \\
\text { ratio }\end{array}$ & Prob. \\
\hline \multicolumn{9}{|c|}{ Family bounciness issues: socioeconomic } \\
\hline $\mathrm{Z} 1$ & 1.103 & 0.458 & 1.203 & 0.309 & 0.893 & 0.896 & 1.014 & 0.972 \\
\hline $\mathrm{Z} 2$ & $0.712 *$ & 0.008 & $0.516^{*}$ & 0.004 & $0.650 *$ & 0.000 & $0.493^{*}$ & 0.000 \\
\hline $\mathrm{Z3}$ & $0.737 *$ & 0.002 & $0.589 *$ & 0.003 & $0.819 *$ & 0.004 & $0.718^{*}$ & 0.005 \\
\hline $\mathrm{Z} 4$ & 1.262 & 0.465 & 1.819 & 0.304 & $2.313^{*}$ & 0.002 & $4.193^{*}$ & 0.002 \\
\hline $\mathrm{Z} 5$ & 0.981 & 0.962 & 0.844 & 0.826 & 0.863 & 0.556 & 0.762 & 0.523 \\
\hline Z6 & 1.179 & 0.132 & $1.410^{*}$ & 0.091 & $1.384 *$ & 0.001 & $1.798^{*}$ & 0.001 \\
\hline $\mathrm{Z7}$ & 1.191 & 0.541 & 1.403 & 0.519 & $1.488 *$ & 0.091 & 1.809 & 0.141 \\
\hline \multicolumn{9}{|c|}{ Family bounciness issues: physical assets } \\
\hline
\end{tabular}




\begin{tabular}{|c|c|c|c|c|c|c|c|c|}
\hline \multirow[t]{3}{*}{ Variable } & \multicolumn{4}{|c|}{ Dependent variable I1 } & \multicolumn{4}{|c|}{ Dependent variable I2 } \\
\hline & \multicolumn{2}{|c|}{ Ordered probit } & \multicolumn{2}{|c|}{ Ordered logit } & \multicolumn{2}{|c|}{ Ordered probit } & \multicolumn{2}{|c|}{ Ordered logit } \\
\hline & $\begin{array}{l}\text { Odds } \\
\text { ratio }\end{array}$ & Prob. & $\begin{array}{l}\text { Odds } \\
\text { ratio }\end{array}$ & Prob. & $\begin{array}{l}\text { Odds } \\
\text { ratio }\end{array}$ & Prob. & $\begin{array}{l}\text { Odds } \\
\text { ratio }\end{array}$ & Prob. \\
\hline $\mathrm{Z} 8$ & 0.832 & 0.470 & 0.691 & 0.431 & 1.273 & 0.193 & 1.471 & 0.220 \\
\hline Z9 & 1.062 & 0.823 & 1.015 & 0.972 & 1.288 & 0.208 & 1.455 & 0.275 \\
\hline $\mathrm{Z} 10$ & 0.855 & 0.292 & 0.740 & 0.261 & 1.042 & 0.681 & 1.102 & 0.590 \\
\hline Z11 & 1.441 & 0.174 & 1.800 & 0.231 & $1.795^{*}$ & 0.002 & $2.766^{*}$ & 0.001 \\
\hline \multicolumn{9}{|c|}{ Family bounciness issues: livelihood strategy and behaviour } \\
\hline $\mathrm{Z} 12$ & $2.097^{*}$ & 0.004 & $4.044 *$ & 0.006 & 1.055 & 0.752 & 1.080 & 0.795 \\
\hline Z13 & 1.072 & 0.622 & 1.142 & 0.632 & 1.050 & 0.632 & 1.090 & 0.623 \\
\hline Z14 & 1.220 & 0.220 & 1.442 & 0.220 & 1.193 & 0.152 & 1.222 & 0.180 \\
\hline Z15 & 0.781 & 0.267 & 0.631 & 0.273 & 1.118 & 0.455 & 1.201 & 0.476 \\
\hline Z16 & 1.086 & 0.615 & 1.137 & 0.664 & 1.048 & 0.682 & 1.072 & 0.721 \\
\hline Z17 & $1.672 * *$ & 0.038 & $2.601 * *$ & 0.034 & 1.025 & 0.850 & 1.057 & 0.808 \\
\hline \multicolumn{9}{|c|}{ Climatic issues } \\
\hline $\mathrm{Z} 18$ & 0.855 & 0.310 & 0.796 & 0.384 & $0.843 * * *$ & 0.097 & $0.746 * * *$ & 0.093 \\
\hline Z19 & 0.677 & 0.151 & 0.465 & 0.124 & $0.488^{*}$ & 0.000 & $0.302^{*}$ & 0.000 \\
\hline Z20 & 0.867 & 0.337 & 0.751 & 0.296 & 0.845 & 0.136 & 0.754 & 0.141 \\
\hline $\mathrm{Z} 21$ & 1.307 & 0.221 & 1.450 & 0.334 & $1.630^{*}$ & 0.001 & $2.265^{*}$ & 0.001 \\
\hline $\mathrm{Z} 22$ & 0.981 & 0.923 & 1.102 & 0.792 & 0.803 & 0.151 & 0.693 & 0.160 \\
\hline Z23 & 1.060 & 0.721 & 1.045 & 0.887 & 0.980 & 0.872 & 0.978 & 0.918 \\
\hline Z24 & 0.945 & 0.681 & 0.898 & 0.674 & 1.058 & 0.564 & 1.128 & 0.484 \\
\hline $\mathrm{Z} 25$ & 1.060 & 0.647 & 1.150 & 0.536 & 0.995 & 0.968 & 0.981 & 0.916 \\
\hline Z26 & 0.003 & 0.981 & 1.034 & 0.888 & 1.113 & 0.302 & 1.194 & 0.311 \\
\hline $\mathrm{Z} 27$ & 0.903 & 0.471 & 0.840 & 0.497 & 0.904 & 0.321 & 0.844 & 0.355 \\
\hline Z28 & 1.211 & 0.212 & 1.482 & 0.152 & 1.060 & 0.625 & 1.108 & 0.615 \\
\hline Z29 & 0.856 & 0.344 & 0.756 & 0.336 & 1.044 & 0.664 & 1.073 & 0.726 \\
\hline $\mathrm{Z} 30$ & 0.983 & 0.925 & 0.971 & 0.920 & 0.933 & 0.590 & 0.891 & 0.593 \\
\hline Z31 & $0.563^{*}$ & 0.002 & $0.328^{*}$ & 0.001 & 0.831 & 0.150 & 0.717 & 0.130 \\
\hline Z32 & 1.357 & 0.100 & 1.690 & 0.113 & 1.031 & 0.822 & 1.071 & 0.770 \\
\hline Z33 & $1.356^{* *}$ & 0.045 & $1.827 * *$ & 0.034 & 1.209 & 0.102 & $1.402 * * *$ & 0.097 \\
\hline Z34 & 0.810 & 0.152 & 0.680 & 0.145 & 0.875 & 0.217 & 0.786 & 0.191 \\
\hline Z35 & 0.801 & 0.151 & 0.691 & 0.192 & 0.836 & 0.103 & $0.731 * * *$ & 0.090 \\
\hline Z36 & 0.888 & 0.330 & 0.801 & 0.304 & 1.112 & 0.265 & 1.187 & 0.290 \\
\hline $\begin{array}{l}\text { Pseudo R- } \\
\text { squared }\end{array}$ & 0.349 & & 0.353 & & 0.305 & & 0.304 & \\
\hline $\begin{array}{l}\text { Prob (LR } \\
\text { statistic) }\end{array}$ & $<0.0000001$ & & $<0.000000$ & & $<0.0000001$ & & $<0.0000001$ & \\
\hline $\begin{array}{l}\text { Sample } \\
\text { size }\end{array}$ & 400 & & 400 & & 400 & & 400 & \\
\hline
\end{tabular}

Note: $*, * *, * * *$ designates substantial at $1 \%, 5 \%, 10 \%$ significance level, correspondingly.

In relations of odds ratios, consequences from the obtainability of nutrition at family (I1) logit model shows that holding supplementary belongings relentless, there is a $160.1 \%$ upsurge of odds of obtainability of nutrition for the family (I1) for a one-unit rise in information around captivating protection in contradiction of dengue, malaria (Z17). The odds of 
family nutrition obtainability (I1) for a family purchasing unpackaged quantity of food (Z12) is $304.4 \%$ higher than the odds of household food availability (I1) for a household without purchasing an unpackaged quantity of nutrition. For a unit upsurge in the wages ratio (Z6), the odds in service of obtainability of nutrition at family (I1) are surged by 1.410 or $41.0 \%$. Holding other things constant, a unit rise in climatic subjects upsetting the kitchen environment (Z31) raises the odds in favor of unobtainability of nutrition in a family (I1) by (1-0.328), or 67.2\%. For a unit growth in scarcity level or decline of family poverty/financial standing (Z3), the odds in favor of unobtainability of nutrition in a family (I1) rises by (1-0.589) or $41.1 \%$. Similarly, there is a $48.4 \%$ rise of odds of unobtainability of nutrition in a family (I1) for a one-unit growth in the number of institute profitable families (Z2).

The consequences for family standing of nutrition convenience (I2) models display that among the climatic issues, normal calamities at the resident flat (Z18), climatic influence on revenue (Z19), climatic influence on family nutrition stowage structure (Z21), climatic influence on family hygiene structure (Z33), and climatic influence on growths of short-term nutrition values (Z35) are statistically important. Similarly, family conveyance (Z11), family deficiency/financial standing (Z3), receiving proportion (Z6), spouse engaged in a profession (Z4), and quantity of school going youngsters (Z2) are statistically important.

Rendering to the probit model, families having investments (Z7) also display a statistically important association with family standing of nutrition convenience. With orientation to the nutrition convenience at family (I2) logit model, the odds ratio designate that holding other things constant, for a unit growth in climatic influence on family nutrition stowage structure (Z21), the odds in favor of nutrition safety in family (I2) grow by 2.265 or $126.5 \%$. Similarly, there is a 79.8\% growth of odds of nutrition convenience in family (I2) for a one-unit rise in earnings ratio (Z6). The odds of family nutrition convenience (I2) for family having conveyance (Z11) are 176.6\% advanced than the odds of family without having transference. The odds of family convenience (I2) for spouse being active (Z4) are 319.3\% higher than the odds of family without spouse engaged in an occupation. The odds of family nutrition convenience (I2) for family having investments (Z7) are $80.9 \%$ greater than the odds of family without investments.

For this model, the odds on climatic issues designate that holding other things unbroken, for a unit rise in expected adversities at the native flat (Z18), the odds in favor of nutrition convenience in a family (I2) declines by (1-0.746) or $25.4 \%$. Similarly, there is a $69.8 \%$ decline of odds of nutrition convenience in a family (I2) for a one-unit growth in climatic influence on revenue (X19). For a unit growth in climatic influence on the raises of short-time nutrition values (Z35), the odds in favor of nutrition convenience in a family (I2) declines by (1-0.731) or $26.9 \%$. There is a $28.2 \%$ decline of odds of nutrition convenience in a family (I2) for a one-unit rise in family scarcity/financial standing (Z3). For a unit rise in the number of school going teenagers (Z2), the odds in favor of nutrition convenience at family (I2) declines by (1-0.493) or $50.7 \%$. Though, in the model, some of the variables display unanticipated cyphers with admiration to their connection with family nutrition safety, such as climatic influences on hygiene structure (Z33). Similarly, the climatic influence on family hygiene structure (Z33) and the number of the odds in favor of nutrition convenience are in a family (I2). Therefore, new-fangled extra revisions need to be commenced to excuse the uncommon behavior of these scarce variables.

\section{CONCLUSION}

The learning treasured that numerous suppleness issues and climatic issues are statistically important to enlighten the family rank of nutrition safety. It also discovered that these issues vary between nutrition safe and unconfident collections. Temperature variation is the main possible hazard to family nutrition safety in Malaysia. Therefore, to confirm supportable family nutrition safety in the nation, environment alteration must be combined into the project of the Malaysian nutrition safety programs. Furthermore, nutrition safety methods must identify weather modification as an imperative carter. This incorporation would surge family ability to adjust to climatic variation. Together, temperature alteration revision methods and plans to decrease susceptibility to temperature alteration would also upsurge family nutrition safety.

Vindicated selections are significant after long-term development. Persons who are defenseless should be authorized and heartened to familiarize to weather alteration by emerging bounciness over reserves in wellbeing, communal defense, teaching, substructure, and extra approaches. Nursing climate excesses and enterprise policies for adversity groundwork is also very significant. Assumed these belongings and the possessions wanted to acclimatize them, possessions pragmatic to understanding the justifiable growth areas might be combined into extenuation programs of climatic alteration. Moreover, the isolated segment should support vindication approaches, such as lively competence, renewable 
liveliness, progresses, and organization, which, for instance, comprises of barriers, flood-resistant stowage amenities, typhoon housings, and methods for depressing water damage in delivery organizations.

Lastly, native, state, and provincial managements must provide adequate possessions to contract with the tests of temperature alteration. They should emphasize on the structure of capability in groups that are chiefly in danger of nutriment uncertainty and climatic variations. Original lessons should also be assumed to authorize or discard the general answers of this learning. The results of the learning are empirically new. Therefore, it has a possibility to discover this subject as supplementary. The consequences of this learning can be explored and authenticated in contradiction of other socioeconomic issues, demographic issues, diverse sites, diverse financial clusters, and diverse dimensions that are equal to nutrition safety.

\section{ACKNOWLEDGEMENT}

Financial assistance provided by the Geran Penjanaan (13945), University Utara Malaysia is gratefully acknowledged.

\section{REFERENCES}

Bala, B. K., Alias, E. F., Arshad, F. M., Noh, K. M., \& Hadi, A. H. A. (2014). Modelling of food security in Malaysia. Simulation Modelling Practice and Theory, 47: 152-164

Balatibat, E. M. (2004). The Linkages between Food and Nutrition Security in Lowland and Coastal Villages in the Philippines. PhD Thesis. Wageningen: Wageningen University. 236p.

Campell, C. (1991). Food Security: A Nutritional Outcome or a Predictor Variable? The Journal of Nutrition. American Institute of Nutrition, 121(3): 277-283.

Coates, Jennifer, Anne Swindale, \& Paula Bilinsky (2007). Household Food Insecurity Access Scale (HFIAS) for Measurement of Household Food Access: Indicator Guide, vol. 3. Washington, D.C.: Food and Nutrition Technical Assistance Project, Academy for Educational Development. 32p.

Cristofar, Sharron P., \& P. Peter Basiotis (1992). Dietary intakes and selected characteristics of women ages 19-50 years and their children ages 1-5 years by reported perception of food sufficiency. Journal of Nutrition Education, vol. 24 No. 2, pp. 53-58.

Economic Commission for Africa (ECA) (2004). Land Tenure Systems and Their Impacts on Food Security and Sustainable Development in Africa. Addis Ababa. 129p.

Energy Information Administration (EIA) (2005). International Energy Annual 2005 - CO2 World Carbon Dioxide Emissions from the Consumption of Coal, 1980-2006 (Million Metric Tons of Carbon Dioxide). Washington, D.C.: Government of the United States. 216p.

FAO (Food and Agricultural Organization), (1996). Implications of economic policy for food security: A training manual, Rome. 199p.

FAO, (2008). Climate change and food security: a framework document, FAO, Rome, Italy. 197p.

FAO. (2003). Trade reforms and Food security: Conceptualizing the Linkages. Rome: FAO. 203p.

FAO. (2005). Bioenergy. Document No. COAG/2005/7. Rome. 237p.

FAO. (2010). Climate-smart" agriculture: policies, practices and financing for food security, adaptation and mitigation. Rome. 191p.

Frankenberger, T. R. (1992). Indicators and data collection methods for assessing household food security. In Household Food Security: Concepts, Indicators, and Measurements: a Technical Review, Simon Maxwell and Timothy R. Frankenberger, eds. New York: UNICEF; Rome: IFAD. 256p.

Giraldo, D. P., Betancur, M. J., \& Arango, S. (2008). Food security in developing countries: a systemic perspective, in: Paper Presented at the International Conference of the System Dynamics Society held on July 20-24 2008 at Athens, Greece. 74p.

Haddad, L., Kennedy, E., \& Sullivan, J. (1994). Choice of Indicators for Food Security and Nutrition Monitoring. Food Policy, 19 (3), 329-343.

Hindin, M. J. (2006). Women's input in household decision and their nutritional status in three resource-constrained settings. Public Health Nutrition, vol. 9, No. 4, pp. 485-493. 
Huang, H. von Lampe, M. \& van Tongeren, F. (2010). Climate change and trade in agriculture. Food Policy, 36: 9-13.

ILO. (2007). Chapter 4. Employment by sector. In Key indicators of the labour market (KILM), 5th edition. 109p.

IPCC (2007).Climate change: the physical science basis. Fourth assessment report of the IPCC. Cambridge, United Kingdom: Cambridge University Press. 235p.

Iram, Uzma, \& Muhammad S. Butt (2004). Determinants of household food security: an empirical analysis for Pakistan. International Journal of Social Economics, vol. 31, No. 8, pp. 735-766.

Lovendal, Christian Romer, \& Macro Knowles (2006). Tomorrow's hunger: a framework for analysing vulnerability to food security. Research Paper, No. 2006/119. Helsinki: United Nations University - World Institute for Development Economic Research. 119p.

Maxwell, S. \& M. Smith. (1992). "Household Food Security: a Conceptual Review." In Household Food Security: Concepts, Indicators, Measurements: A Technical Review. S. Maxwell and T. R. Frankenberger. New York and Rome: UNICEF and IFAD. 197p.

Ministry of Science, Technology and the Environment (MOSTE) (2001). National Response Strategies to Climate Change. Putrajaya, Malaysia. 216p.

Myntti, C. (1993). Social determinants of child health in Yemen. Social Science \& Medicine, vol. 37, No. 2, pp. 233-240.

National Census, (2010). Population and Housing Census of Malaysia, 2010. 177p.

National Hydraulic Research Institute of Malaysia (NAHRIM) (2006). Final Report: Study of the Impact of Climate Change on the Hydrologic Regime and Water Resources of Peninsular Malaysia. National Hydraulic Research Institute of Malaysia (NAHRIM) and California Hydrologic Research Laboratory (CHRL), Malaysia. 181p.

Negatu, W. (2006). Determinants of small farm household food security: evidence from south Wollo, Ethiopia. Ethiopian Journal of Development Research, vol. 28, No. 1, pp.1-29.

Nyariki, D. M., \& Steve, W. (1997). Household food insecurity in Sub-Saharan Africa: lesson from Kenya. British Food Journal, vol. 99, No. 7, pp. 249-262.

Olson, C. M. (1997). Factors contributing to household food insecurity in rural upstate New York. Family Economics and Nutrition Review, vol. 10, pp. 2-17.

Paterson, R. \& Lim, N. (2010). How will climate change affect mycotoxins in food? Food Research International, 43: 1902-1914.

Pfeiffer, J., Stephen, G., \& Lucy, R. L. (2001). Intra-household resource allocation and child growth in Mozambique: an ethnographic case-control study. Social Science \& Medicine, vol. 53, No. 1, pp. 83-97.

Piaseu, N. (2006). Factors affecting food insecurity among urban poor in Thailand. South African Journal of Clinical Nutrition, vol. 18, pp. 156-161.

Pielke, R. (2007). Lifting the taboo on adaptation. Nature, vol. 445, No. 7128, pp. 597-598.

Riely, F., Mock, N., Cogill, B., Bailey, L., \& Kenefick, E. (1999). Food Security Indicators and Framework for use in the Monitoring and Evaluation of Food Aid Programs, Food and Nutrition Technical Assistance, Washington, DC. 97p.

Rose, D. \& Peter, P. B. (1995). Improving federal efforts to assess hunger and food insecurity. FoodReview, vol. 18, No. 1 (Jan-Apr), pp. 18-23.

Schmidhuber, J. \& Tubiello, F. N. (2007). Global food security under climate change, Proc. Natl. Acad. Sci. 104 (2007) 19703-19708.

Stern, Nicholas (2007). The Economics of Climate Change: the Stern Review. Cambridge, U.K.: Cambridge University Press. Pp. 265-280.

Tisdell, C. (1996). Economic indicators to assess the sustainability of conservation farming projects: an evaluation. Agriculture, Ecosystems and Environment, vol. 57, No. 2-3, pp. 117-131.

Yamane, T. (1967). Statistics: An Introductory Analysis, edition 2. New York: Harper and Row; Tokyo: John Weatherhill. 1130p.

Yuhanz, H., Seraila, A., Muhammed, S. \& Saleh, A. H. (2016). Sitting anthropometrics groupings of school children from grades 1 to 5. Malaysian Journal of Public Health Medicine, Special Volume 1: 80-85. 


\section{APPENDIX}

I1 = Household food availability in the last one month,

I2 = Household status of food accessibility,

$\mathrm{Z} 1$ = Education level,

$\mathrm{Z} 2$ = Number of school going children,

Z3 = Household poverty/economic status,

$\mathrm{Z} 4$ = Spouse doing job,

Z5 = Head of household having supplementary job,

Z6 = Earnings ratio (earning family member/total family member)

$\mathrm{Z7}=$ Household having any savings,

$\mathrm{Z8}=$ Locality,

Z9 = Ownership of house,

$\mathrm{Z} 10$ = Type of home,

Z11 = Household having any transport for buying food,

Z12 = Household buying bulk amount of food,

Z13 = Household having neat and clean kitchen and dining place,

Z14 = Household having a hygienic sanitation facility,

Z15 = Household managing waste properly,

Z16 = Household having knowledge about maintaining nutritious and hygienic way of cooking and washing food,

Z17 = Household having knowledge about taking precaution against dengue, malaria, etc.,

Z18 = Occurrences of natural disasters such as flood, cyclone, landslides, etc. at local level,

Z19 = Climatic issues and related disease reduce income,

Z20 = Climatic issues affect household food collection system,

Z21 = Climatic issues affect household food storage system (e.g. refrigerator, packaging),

Z22 = Climatic issues affect household food storage process (e.g. dry, salty, oily),

Z23 = Climatic issues increase household food storage cost,

Z24 = Climatic issues affect household usage or utilization of land,

$\mathrm{Z} 25$ = Climatic issues reduce normal food test,

Z26 = Climatic issues reduce food longevity,

$\mathrm{Z} 27$ = Climatic issues affect household food choice and habit,

Z28 = Climatic issues affect household cooking system (e.g. cooking by gas or stove not by woods),

Z29 = Climatic issues affect cooking time and amount (e.g. large amount of cooking together or several time cooking for hot food or several times heating for not rotating),

$\mathrm{Z} 30$ = Climatic issues cause to eat outside or buy ready food from outside,

$\mathrm{Z} 31$ = Climatic issues affect the environment and cleanness of kitchen,

Z32 = Climatic issues affect household waste management,

Z33 = Climatic issues affect home sanitation system,

Z34 = Climatic issues hamper food aid services and food supports program,

Z35 = Climatic issues increase short-term food prices,

Z36 = Climatic issues cause to increase food price in restaurant. 